\title{
Malignant Epicardial Neoplasm
}

National Cancer Institute

\section{Source}

National Cancer Institute. Malignant Epicardial Neoplasm. NCI Thesaurus. Code C4568.

A malignant neoplasm that affects the inner layer of the pericardium. 